by page. On many systems, pushing the ALT and $\mathbf{L}$ keys simultaneously will send everything to the printer from that point on (press the same keys again to turn off the printer dump). You may want to download the briefing to a disc for further analysis.

\section{Task 3: Analysis.}

After reading the briefing, answer the questions outlined at the outset of this exercise. Write your results in a brief paper. Where appropriate, include direct quotes from both the articles and the briefing.

\begin{abstract}
About the Author
Stephen Frantzich is professor and chair of the department of political science at the U.S. Naval Academy. He has served as president of the Computers and Multi-Media Users section of APSA and directs the Poli-

Ware program of the Association. He uses technology heavily in teaching and was chosen as the outstanding instructor at the $\mathrm{Na}$ val Academy in 1990. He is the coauthor of American Government: The Political Game, and Congress: Games and Strategies (Brown and Benchmark Publishers) both of which come with software designed by the author.
\end{abstract}

\title{
Teaching About American Democracy Through Historical Cases
}

\author{
Sheldon Appleton, Oakland University
}

P ub remind us how fragmentary most citizens' understanding of American democracy is. How does Whitewater differ from Iran-Contra? From Watergate? From other less famous events in our country's political history? Just what was it that Richard Nixon did that led to his resignation under threat of imminent impeachment? Why wasn't Ronald Reagan impeached, too? What kind of findings in the Whitewater investigation would warrant the initiation of impeachment proceedings against Bill Clinton?

Not only the general public, but our students as well, have great difficulty coming up with a consistent set of answers to these questions, as most of those who have taught the introductory American government course can attest. Despite excellent discussions of the meanings of democracy in many introductory texts, a good number of students still cannot deal with these questions after completing the course, or even in some cases after completing a major in political science!

My experience has been that the most effective way for students to gain an understanding of democracy in the real world is to supple- ment their readings in democratic theory with cases. These cases require them to build and use theories to make determinations about which polities are "democratic" and which sets of decisions or policies have been made "democratically." How do we know that the political systems of the United States and Great Britain are "democratic," while those of, say, Iraq, the People's Republic of China or pre-Aristide Haiti are not? (Many students respond not by applying the "principles" of democracy outlined in their readings or in class, but via comparison with the United States. The more like our own a political system is seen to be, the more likely students are to consider it "democratic." For this reason, some first-year students may even be a bit skeptical of parliamentary systems.) The idea is to get students to develop sets of criteria that allow them both to begin to make such discriminations and to gain a fuller understanding of the meanings of democracy in practice.

Over many years of trial and error, I have found a number of cases or class exercises to be most useful in helping students learn to make these discriminations and gain this understanding. At the most elementary level, in the introductory American government course, a simple exercise is introduced early in the semester, just after students have read the chapters on democracy or ideologies and on the Constitution. Students are assigned to read the U.S. Constitution and to write a few paragraphs on whether they believe that document as originally writtenincluding the Bill of Rights, but no subsequent amendments-is "democratic," and why. The students are asked also whether the Constitution today is more or less "democratic" than the original version, and why. This calls their attention to the changes which have taken place over the past 200 years and perhaps also to the need to have criteria beyond just "being like the U.S."'

The students are then divided into small groups (of about eight) where they spend a class session discussing this issue. The instructor roves from group to group, listening, and occasionally commenting on what is said. Each group is asked to try to come to agreement on these questions and to state what they have agreed on a large index card. In small classes, or in those where assistants are avail- 
able, each student's brief essay is returned with comments and counted as a small part of a class participation grade. In large classes, a record is kept merely of whether or not the assignment was handed in

In their group discussions, many students say that the eighteenthcentury version of the Constitution was democratic, because it provided for free elections. Others point out that the document implicitly accepted the institution of slavery and permitted restriction of the electorate by the states to a minority of the population. A common response to this objection is that the U.S. was "democratic for its time." As noted above, some simply identify democracy as the American way: whatever the United States did or does is "democratic."

During the following class session, I critique the discussion, calling attention to obvious inconsistencies, responding to students' questions and attempting to differentiate the various approaches to defining democracy which the students-and political theorists-have proposed. Hearing the students' conversations and reading some or all of their brief essays helps enormously in targeting my remarks to that particular class.

There is rarely time in the introductory course to go beyond this exercise. In smaller, upper level courses, however, the opportunities are many. With about 20-30 students enrolled, my practice has been to create four or five groups of five to six students. After a lecture introducing the case and posing and framing the questions to be dealt with, each group is given about two weeks of class time to produce a group paper of about 1,000-1,200 words. (In fact, most students spend many hours of time meeting outside of class to work on these assignments.)

Again, the instructor moves from group to group listening and occasionally commenting. Readings, often including original source materials (see below), are assigned from a coursepack designed by the instructor and vary from about 30 to 100 pages per case. Group members receive a common grade for this paper-which alarms some; but each student is also evaluated separately for her or his contribution to the group's work. (Students are asked to specify in writing who did what.) These two grades combined count about as much as those for the mid-term exam.

On the last day allotted for the case, each group submits its paper at the start of the class, and then takes its turn summarizing and defending - in about ten minutes - the position it has taken. (This dialogue can become extremely lively when, as often happens, different groups have taken opposing positions.) In

\section{Despite excellent} discussions of the meanings of democracy in many introductory texts, a good number of students still cannot deal with these questions after completing the course, or even in some cases after completing a major in political science!

groups which cannot reach agreement, individuals or sub-groups are invited to submit dissenting papers. After hearing these colloquies and reading the papers submitted, I use one more class session to try to advance the analyses the students have presented, deal with disagreements and inconsistencies and reinforce what I hope have been the concepts and skills learned.

Exams for these courses always include a brief (two- to- four-page) fictional case that calls for the students to display the conceptual clarity and analytical skills the cases are designed to teach.

A useful case to begin with involves the Louisiana Purchase. As documented in Graber (1968), President Thomas Jefferson regularly acted secretly, withheld relevant information from both the public and the Congress, and presented the Senate with a fait accompli. He himself believed that he may have exceeded his authority under the Constitution, an opinion apparently shared by no less an authority on the document than his Secretary of State, James Madison.

This case is worthy of consideration for a number of reasons. Unlike Whitewater, for example, it happened too long ago to engage any partisan biases the students may have. It involves one of the most revered figures in American history, himself a founder and author of the Declaration of Independence. Could such a man act undemocratically? What electorate chose Jefferson? Who represented the interests of the inhabitants of the Louisiana territory?

Best of all, this case raises an issue unimaginable to many students: can the "undemocratic" action be the "right" one? Can it be that Jefferson acted "undemocratically," but that, in the circumstances, the acquisition of Louisiana was sufficiently critical to the development of the nation that it was worth some departure from democratic principles? (Indeed, this may have been Jefferson's view.) What are the costs of such departures?

My experience has been that students will resist ferociously accepting the possibility that there can be a conflict between "democracy" and "rightness" ("morality?"). Many argue, instead, that Jefferson's actions must have been "democratic" because they were "right" or in the national interest. Students are assigned to discuss both whether they believe Jefferson acted "democratically" and what they would have done in his place.

Another stimulating case involves tracking the policies of Franklin D. Roosevelt in the years prior to Pearl Harbor. In this case, some early survey data are available to provide clues about the preferences of "the people" on questions relating to American involvement in the early years of World War II. These help to raise issues about the relationship of public opinion to "democracy" (as well as, if you wish, about the rela- 
tionship between poll results and public opinion). Students' notions of "democracy" usually involve the criterion of carrying out the will of the people. This case helps them to understand that it isn't always easy to know what the "will of the people" is, or to carry it out when we do know. The advisability (and feasibility) of government by opinion poll may be discussed here.

The case also raises questions of manipulation of public opinion through withholding information and providing misleading information. For example, Roosevelt reported German submarine attacks on the U.S. destroyers Kearney and Reuben James without mentioning that at the time of the attacks, the U.S. ships were reporting the subs' positions to nearby British ships. (See Russett 1972 and Page and Shapiro 1992 for discussions which make usable readings for classroom packets on this case.)

Helpfully, an election was held in the middle of the period under consideration, during which Roosevelt made such statements as: "Your boys are not going to be sent into any foreign wars." To what extent, if any, do such statements invalidate the legitimation conferred by the elections that are part of almost every student's criteria for "democracy"? Finally, the issue of "democracy" versus "morality" is raised again. We know the Nazis were "bad guys." Since Roosevelt was convinced it was right and in the best interests of the nation to fight them, as most students will believe it was, would it have been moral for him to follow public sentiment to stay out of the war? What are the parameters separating "democratic" leadership from "undemocratic" manipulation?

The assignment in this case is to decide how "democratic" FDR's actions were over this period, and to try to state what it was that the public wanted and how well

Roosevelt's and the Congress's actions corresponded to public preferences. Students are also asked whether it is more important for a president to do what he or she believes the people want in a case such as this, or what he or she believes to be in the national interest whether the public seems to agree or not. Considering these questions also offers a good opportunity for discussing Page and Shapiro's thesis that, given correct information, collective public responses to policy issues are rational. After reviewing the facts and available survey data from this and subsequent cases, do the students agree?

These are difficult questions. I suggest to the students that they may wish to begin by developing in their small group discussions a basic definition of "democracy." What are the rock bottom requirements for a system or set of policies to be appropriately called "democratic"? The students are warned that a definition based on criteria that would almost always or almost never be met in the real world will not be helpful to them. For instance, a definition which called only for elections to be held would permit Stalinist Russia or the old white South African regime to be called "democratic." On the other hand, requiring that every resident have equal weight in the making of all governmental decisions would disqualify all political systems above a minimal size. I have found that it may take hours of discussion, puzzlement, and occasional despair for groups of half a dozen students-most of them majors-to come up with an even minimally workable definition.

The World War II case can be used to segue quite naturally to one reviewing how Lyndon Johnson conducted U.S. involvement in Vietnam, starting with the Gulf of Tonkin incident (linked with the Kearney and Reuben James incidents by Russett among others). The Tonkin resolution also raises the issue of Congressional authority. Survey data on U.S. policy during the war in Vietnam is quite voluminous (Mueller 1973, 1984; Mayer 1992; Page and Shapiro 1992) and can be used to make many arguments about public support-or lack of support-for the policies followed.

Discussion can be renewed about the difficulty of knowing what "the people" want, the methodological problems involved in polling, the possibilities of discontinuity be- tween what the public may want and what it is possible to achieve, about manipulation of opinion through withholding information and even providing "information" known to be false, and about the boundaries between manipulation and leadership. In addition, there is an opportunity to study the effectiveness of a protest movement thought by some to have been counterproductive (Mueller 1984) and by others to have been an important factor in ending U.S. involvement (Page and Shapiro 1992).

Here again, the assignment includes whether the president acted "democratically," what it was that the public wanted, and how closely Johnson's and the Congress's actions corresponded to the public's preferences. If there is time, questions can be added about the effectiveness of the protest movement and perhaps how it might have been made more effective. (The Louisiana Purchase, World War II, and Vietnam cases complement one another and may also usefully be pursued together.)

Then, of course, there is Richard Nixon and Watergate. Here students need to be asked whether or not they would have voted to impeach Nixon, and why? This raises the slippery question of what constitutes an "impeachable" offense. The most frequent student response is that the president broke the law, the implicit accusation Nixon defended himself against with his famous statement that he was "not a crook." This offers the opportunity to impress upon students the distinction between ordinary and constitutional law, and the importance of the concept of limited government.

Lyndon Johnson, when president, was caught driving above the speed limit. Clearly he "broke the law." Yet students readily agree that it would have been absurd to impeach him for this. Or, suppose a president were to be found, in the fashion of the moment, to have employed a housekeeper without paying social security taxes? Apparently, this disqualifies people for Cabinet appointments, but is it grounds for impeachment as well? Or suppose a president were caught 
shoplifting some small item, or as has sometimes been charged, cheating on an income tax return? Would any of these be grounds for impeachment?

In addition to references to the case of Andrew Johnson, Watergate invites comparison with the Iran-Contra episode (Schudson 1992). I have found it most useful to pair the Iran-Contra case with one involving President Harry Truman's dismissal of General Douglas MacArthur. Each of these historical episodes involves the firing of a military officer by a president, albeit under very different circumstances. In each case, the military "hero" fared very well in public support, at least at first, and the president's popularity nosedived. MacArthur, of course, posed a bureaucratic-political challenge to Truman, rather than a legal or constitutional one. Both officers maintained that they followed what they understood to be the orders of their presidents. Both had or developed political ambitions. In both instances, Congressional hearings and memoirs of the dramatis personae provide fine case materials (U.S. House of Representatives Select Committee to Investigate Covert Arms Transactions with Iran 1988; U.S. Senate Committees on Armed Services and Foreign Relations 1951; MacArthur 1964; North 1992; Reagan 1990; Truman 1956). In the Iran-Contra case, the report of the special prosecutor is an excellent resource (Walsh 1994).

Questions that can be put to students in these cases include whether the presidents had the right to dismiss the military officers; whether they acted "democratically" in doing so; whether they, the students, would have done so had they been president and why. Students are also asked what they would have done if they had been MacArthur or North, believing that the policies they advocated were the best way to defend the interests of their country against Communist enemies. Among the information provided to the students should be opinion survey results showing that the public supported MacArthur's suggestions that the Korean War be expanded, but opposed both the hostage trade and U.S. military support of the contras (Page and Shapiro 1992). Does this influence the students' view of what was the "democratic" course of action in each case? Should it?

Finally, students' understanding of the meaning of American democracy can be enhanced by the study and analysis of national elections. Generally, I use the two most recent presidential campaigns (using the accounts in the special election issues of Newsweek plus selections from Abramson, Aldrich, and Rohde 1994).

The 1988 election draws attention to negative campaigning (Willie Horton et. al.), "valence" issues (e.g., the pledge of allegiance), and the electoral implications of divided outcomes for Congress and the presidency. The 1992 campaign features a three-cornered race with a president elected by less than $40 \%$ of the voters and only about a fifth of the eligible electorate-and without enthusiasm even by some of these. What do these outcomes tell us about "democracy"? How "democratic" is this system? Realistically, could it be made more democratic? How? Are other national political systems more "democratic"? Was the U.S. political system more "democratic" at some time in the past-as the slogan "take back the system" suggests? If so, when and why?

Of course, students will not come up with definitive answers to these questions, any more than political scientists have. But coping with them and discussing them with peers seems likely to make them more sophisticated citizens, more likely than when they entered our classrooms to understand when cherished American political values are threatened.

\section{References}

Abramson, Paul, John Aldrich, and David Rohde. 1994. Change and Continuity in the 1992 Elections. Washington, D.C.: Congressional Quarterly Press.

Graber, Doris. 1968. Public Opinion, the Presidency and Foreign Policy. New York: Holt, Rinehart and Winston.

MacArthur, Douglas. 1964. Reminiscences. New York: McGraw-Hill.

Mayer, William. 1992. The Changing American Mind. Ann Arbor: University of Michigan Press.

Mueller, John. 1973. War, Presidents and Public Opinion. New York: Wiley.

Mueller, John. 1984. "Reflections on the Vietnam Protest Movement and on the Curious Calm at the War's End," and "A Summary of Public Opinion on the Vietnam War." In Vietnam As History, ed. Peter Braestrup. Washington, D.C.: Woodrow Wilson International Center for Scholars.

Newsweek. November 21, 1988 and November 21, 1992. Special Election Issues.

North, Oliver. 1992. Under Fire. New York: HarperCollins.

Page, Benjamin, and Robert Shapiro. 1992. The Rational Public. Chicago: University of Chicago Press.

Reagan, Ronald. 1990. An American Life. New York: Simon and Schuster.

Russett, Bruce. 1972. No Clear and Present Danger. New York: Harper and Row.

Schudson, Michael. 1992. Watergate in American Memory. New York: Basic Books.

Truman, Harry S. 1956. Years of Trial and Hope. Garden City, NY: Doubleday.

United States House of Representatives, Select Committee to Investigate Covert Arms Transactions with Iran and United States Senate, Select Committee on Secret Military Assistance to Iran and the Nicaraguan Opposition, Joint Hearings on the Iran-Contra Investigation-Testimony of Oliver L. North. 1988. Washington, D.C.: Government Printing Office.

United States Senate, Committees on Armed Services and Foreign Relations. 1951. Joint Hearings on the Military Situation in the Far East. Washington, D.C.: Government Printing Office.

Walsh, Lawrence. 1994. Iran-Contra: The Final Report. New York: Random House.

\footnotetext{
About the Author

Sheldon Appleton is professor of politica science at Oakland University in Michigan and the first recipient of its Teaching Excellence Award. He has written on U.S. foreign policy and on the meaning of democracy to Chinese students, and he has served on the editorial board of the American Journal of Political Science. His most recent publication is "Martin Luther King in Life . . A And Memory," The Public Perspective 6:2 (Feb.-March, 1995).
} 